\title{
Learning about the forest using alternative curricula - the Guelph experience
}

\author{
by Andrew M. Gordon ${ }^{1}$, Doug W. Larson ${ }^{2}$, Ray A. McBride ${ }^{3}$, Glen P. Lumis ${ }^{4}$, Kim Rollins ${ }^{5}$ \\ and Sally Humphries ${ }^{6}$
}

\begin{abstract}
The University of Guelph is a mid-sized university in southern Ontario that has many historical underpinnings with respect to both undergraduate and graduate education in forestry and forest-related subjects. Some of the earliest forward-thinking forest policies found in Ontario came from early faculty associated with the predecessor of the University, the Ontario School of Agriculture. Today, the University has numerous faculty in Colleges across campus that are involved in a multitude of teaching and research aspects associated with forested environments. The research-teaching link with respect to forestry is strong and the undergraduate population appears appreciative of this. Undergraduate courses and course segments at both undergraduate and graduate levels exist, and a minor in forest science, housed in the Department of Environmental Biology but drawing on resources from across multiple disciplines, is also available. The University of Guelph is currently evaluating its options with respect to undergraduate education in the forest sciences. Building on past and present strengths, the University is considering offering a non-accredited B.Sc. program that embraces the science and management of forests and the environmental impact and community benefits associated with interventions in the forest.
\end{abstract}

Key words: Ontario forests, historical perspectives, learner-centred undergraduate curriculum, forest environments, forest science, forest and natural resource economics, internationalism, non-accredited B.Sc. undergraduate degree, graduate forest research

L'Université de Guelph est un établissement de taille moyenne du sud de l'Ontario qui est reconnu pour plusieurs de ses développements historiques relativement autant pour sa formation pré-graduée que post-graduée en foresterie et sur les sujets reliés à la foresterie. Certaines des plus anciennes politiques forestières d'avant-garde retrouvées en Ontario proviennent de professeurs associés à ce qui a précédé l'Université, l'École d'agriculture de l'Ontario. De nos jours, l'Université comptent plusieurs professeurs répartis dans les Collèges sur le campus qui sont impliqués dans une multitude de tâches d'enseignement et de recherche reliées aux environnements forestiers. La relation entre la recherche et l'enseignement en matière de foresterie est forte et la population pré-graduée semble apprécier cet état. On retrouve des cours pré-gradués et des segments de cours tant au niveau pré-gradué que gradué, ainsi qu'une mineure en sciences forestières, offerte par le Département de Biologie environnementale mais qui tire ses ressources de plusieurs disciplines. L'Université de Guelph évalue actuellement ses options relativement à l'enseignement pré-gradué en sciences forestières. Comptant sur le passé et les forces actuelles, l'Université considère offrir un programme non-agréé de baccalauréat en sciences qui couvrirait la science et l'aménagement des forêts et l'impact environnemental, ainsi que les bénéfices communautaires associées aux interventions en forêt.

Mots-clés: forêts de l'Ontario, perspectives historiques, programme pré-gradué centré sur l'apprentissage, environnements forestiers, sciences forestières, économie forestière et des ressources naturelles, internationalisation, diplôme pré-gradué de baccalauréat non agréé, recherche forestière post-graduée

\section{Introduction}

The University of Guelph, Guelph, Ontario is a mid-sized, research-intensive university with approximately 13000 undergraduate students enrolled in 90 majors in 11 degree programs and 1800 graduate students enrolled in 49 master's and 27 doctoral programs. It is home to the largest concentration of life scientists dedicated to plant and animal research in Canada and among the top Canadian universities in terms of research grants from national research granting councils. Within the "comprehensive" category of university, the University consistently ranks at the top of, or close to the top of, national polls taken to evaluate the strengths and weaknesses of universities across the country.

\footnotetext{
${ }^{1}$ Dept. Environmental Biology, University of Guelph, Ontario N1G 2W1; author to whom correspondence should be addressed. E-mail: agordon@evb.uoguelph.ca ${ }^{2}$ Dept. Botany, University of Guelph, Ontario N1G 2W1.

${ }^{3}$ Dept. Land Resource Science, University of Guelph, Ontario N1G 2W1.

${ }^{4}$ Dept. Plant Agriculture, University of Guelph, Ontario N1G 2W1.

${ }^{5}$ Dept. Agric. Economics and Business, University of Guelph, Ontario N1G 2W1.

${ }^{6}$ Dept. Sociology and Anthropology, University of Guelph, Ontario N1G 2W1.
}

The University also has a strong commitment to teaching, which is reflected in the breadth of its teaching support services, the mandatory maintenance of a teaching dossier by faculty, and by the fact that it boasts more $3 \mathrm{M}$ teaching awards than any other similarly-sized university in Ontario. A central theme currently being advocated and adopted by many faculty in their teaching spheres is that of learner-centredness (Rimkus and Lauzon 2000), the four pillars of which are self-reliant learning, experiential learning, skills development and the research-teaching link. These were identified by the University in a 1995 Strategic Plan as a primary and critical direction of focus (Strategic Planning Commission 1995). While all components of learner-centredness contribute to a healthy teaching environment, it is the research-teaching link that has fostered much useful feedback from the undergraduate population, especially regarding courses dealing with plants, trees, and forests. The University has a historical and continuing record of accomplishment in forest research (Brassard and Page 1994) and this continues to play an important role in the quality of undergraduate education.

Although the University does not have a declared School of Forestry, and does not offer degrees in Forest Science, the number and breadth of faculty across colleges and departments that 
are involved in researching forest-related issues is significant and has allowed the University to informally embrace forest education effectively at both the undergraduate and graduate level. The purpose of this article is to outline the historical perspective of Guelph's “forest education program," to examine some current examples of forest-related curricula, and to identify future directions for formalizing forest education at the University of Guelph, as an example of alternative education pathways concerned with the basic principles of forest science and the forest environment.

\section{Historical Perspectives on Forestry at the University of Guelph}

In 1874, the Ontario School of Agriculture and Experimental Farm (the pre-cursor of the Ontario Agricultural College (OAC), one of the founding colleges of the University of Guelph, 1964) opened at Guelph and hired as its first professor of Agriculture, William Brown, an arboriculturist from Scotland. Brown was known for his successful reforestation activities in Scotland between 1855 and 1869, and his early reports to his superiors at Guelph indicated that he was keenly aware of the social costs of habitat deterioration and of the economic value of landscape restoration (Larson 1996). In addition to a 250-ha Arboretum, the University owns several small parcels of forested land, several of which are located on campus and are routinely utilized as outdoor teaching laboratories. In honour of Professor Brown and his early perspectives on the utilization of trees and forests to rehabilitate lands, one of these is aptly named Brown's Woods, and is in all likelihood, one of the oldest examples of tree planting for the restoration of ecological processes in the entire province.

Many of the early graduates of the Ontario School of Agriculture, perhaps because of Brown's influence, became prominent leaders in the forestry movement. For example, the first provincial forester, Dr. Judson F. Clarke, appointed in 1904, was an OAC graduate of the class of 1896 (Armson et al. 2001). Brown left the college in 1888 and was succeeded by several sessional lecturers until Edmund J. Zavitz (Fig. 1) was appointed full lecturer in forestry at the Ontario College of Agriculture in the fall of 1905. He was a graduate of McMaster University but had a M.Sc. degree in forestry from the University of Michigan. He stayed at Guelph until 1912, developing the College's tree nursery (Fig. 2), one of the first in Ontario, into a co-operative planting project. He put great emphasis on farm forestry and distributed trees to the farming community for shelterbelt and wasteland plantings (Lambert 1967). During his time at Guelph, Zavitz also taught dendrology to the fledgling school at the University of Toronto and became widely appreciated in forestry circles, interacting with individuals such as Gifford Pinchot (Chief, U.S. Forest Service) and Bernard Fernow (Dean, Faculty of Forestry, University of Toronto). He toured many of the existing sub-marginal lands in southern Ontario by horse and buggy and bicycle, and his shared vision with Premier E.C. Drury made Ontario a showplace for reforestation efforts in Canada (Borczon 1982). His small nursery was eventually moved to St. Williams, where for many years it produced and supplied to the farm community millions of tree seedlings annually. By the end of his career, Zavitz had served not only as one of the first provincial foresters, but also as Deputy Minister of Forestry (1925-1934) and then chief forester until his retirement in 1953.

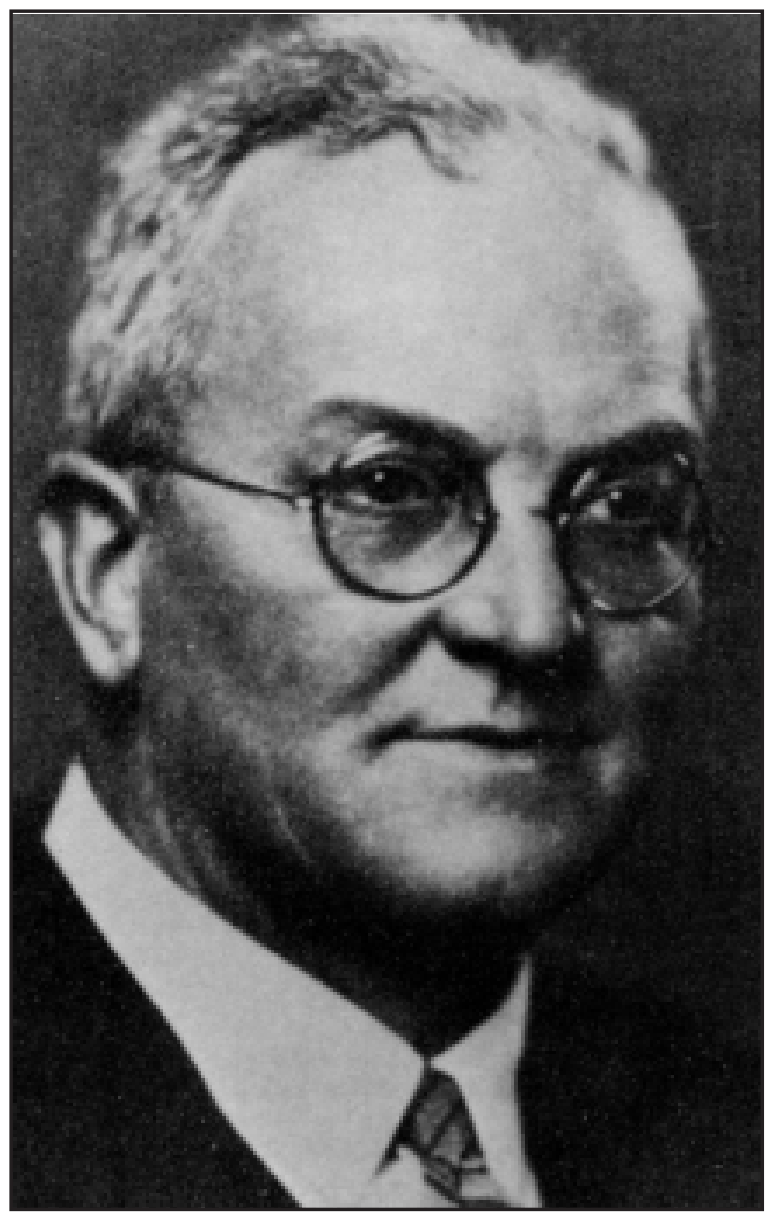

Fig. 1. Edmund John Zavitz, father of forestry in Ontario. He was Professor of Forestry at the University of Guelph from 1905-1912, Deputy Minister of Forestry from 1925-1934 and Chief Forester until his retirement in 1953. His friendship with the farmer-politician, E.C. Drury, led to important reforestation initiatives in southern Ontario. Photo Credit: Ontario Dept. Lands and Forests (former) photo library, Toronto.

Several additional individuals associated with the forest history of OAC and Guelph, and who have had enormous impact on forest practices not only in Ontario but around the world, are also worthy of mention. Dr. Reginald Balch was an OAC graduate of 1921 and 1923. He became director of the Dominion Forest Biology Laboratory in Fredericton where he developed methods for controlling the European spruce sawfly in eastern forests. This was one of the most successful attempts at insect control in entomological history and led to the creation of an entire insect pathology organization in Canada. However, he soon became concerned about the widespread application of chemical spraying, and spoke out widely on this and related issues. In 1965, Dr. Balch gave a series of talks on CBC, which were the first to link current trends in ecological thought with the management of North American forests (Balch 1965).

G. Angus Hills was also an OAC graduate (1937) and later worked with the Canada Agriculture Branch based at the University of Guelph. At one time, he gave guest lectures on forest soils to students in the Faculty of Forestry at the University of Toronto. He eventually became well known around the world 


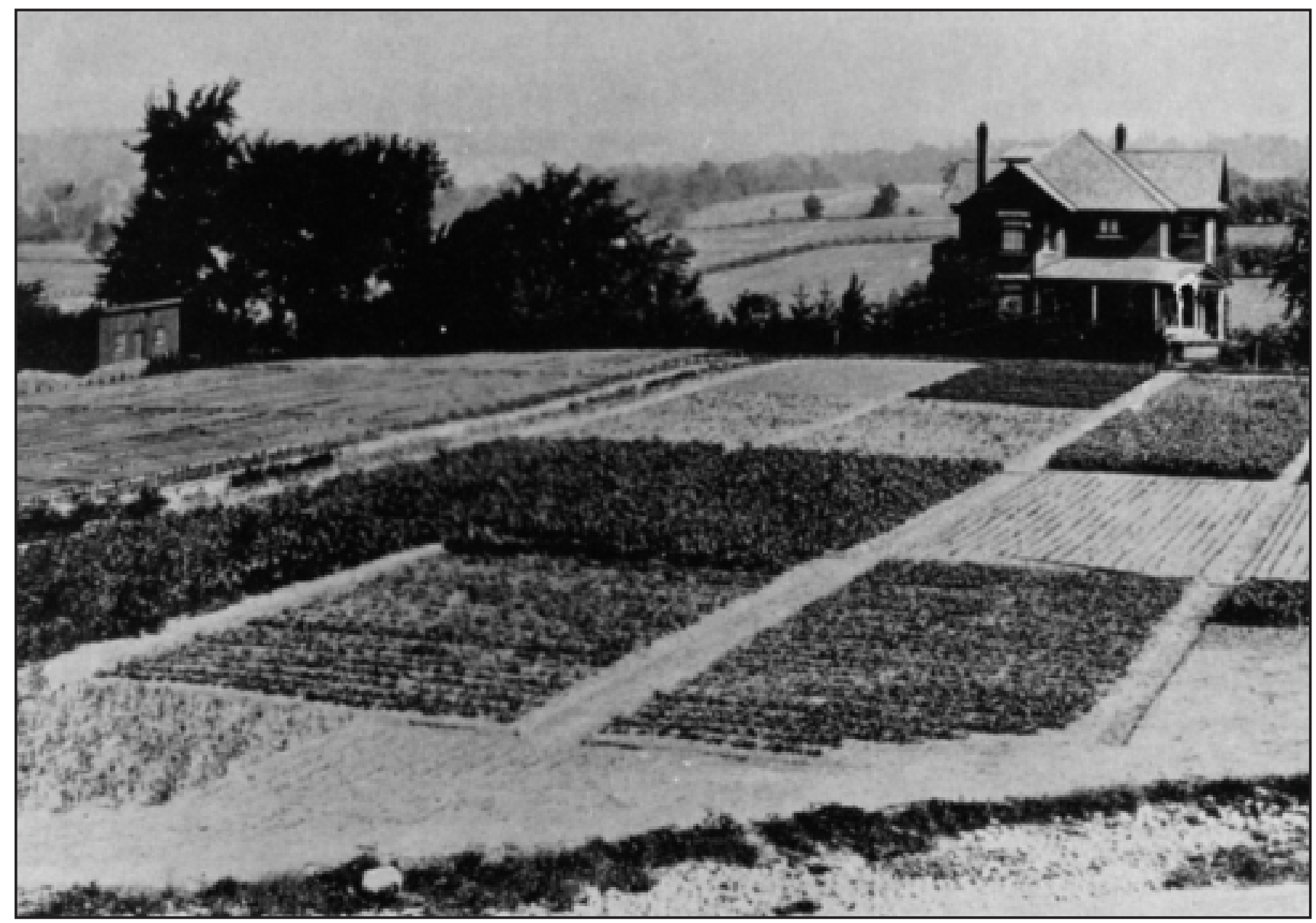

Fig. 2. The original forest tree nursery/seed beds established by E.J. Zavitz at the Ontario Agricultural College. (photo, 1906). Photo Credit: Ontario Dept. Lands and Forests (former) photo library, Toronto.

for his contributions to our understanding of soil-site-forest relationships not only in Ontario but also many parts of Canada (e.g., Hills 1959, Hills and Pierpoint 1960). His thinking was visionary and his premises continue today to form the basis for many forest soil site classification systems and the investigation of the properties of forest soils.

Finally, Herb Richardson was a University of Toronto forestry professor who was seconded to Guelph to instruct in forestry during the 1930s and 1940s. When he finally left the teaching profession, he made major contributions to the development of the Conservation Authority program, which ultimately led to the widespread adoption of the principles associated with good forest and hydrological management, especially in the southern Ontario agricultural landscape (N.R. Richards, former Dean, OAC, personal communication).

Although many individuals in the agricultural, biological and social sciences at the University have contributed to our understanding of forest systems, and continue to do so today, the individuals discussed above are noteworthy for their shared vision of, and dedication to, sustainable forest management systems. From the socio-economic and rehabilitative importance of forest systems advocated by Brown and Zavitz, to the foundations of biology, ecology and the importance of soils espoused by Balch, Hills and others, the collective philosophies and wisdom have been in many instances handed down over the years, from faculty to faculty. These qualities continue to display themselves in the teaching and research programs at the University of Guelph in the forest science sector.

\section{Current Status of Forest Education - Under- graduate}

By the late 1980s, formal courses dealing specifically with issues in forest science were largely housed in the Department of Environmental Biology, in the Ontario Agriculture College. A second-year course entitled "Current Issues in Forest Science" is normally available to a large segment of the undergraduate population and is followed by an advanced course in forest ecology at the fourth-year level (Table 1). There is also a diploma course in agroforestry, which teaches the basic principles of farm woodlot management and forestry to students enrolled in a twoyear diploma in agriculture program, and a graduate level course entitled "Forest Ecosystem Dynamics."

The second-year course includes an evolutionary, ecological, biological and socio-economic overview of the development of trees, forests and forestry and utilizes this information to explore current issues facing forestry professionals and those with differing opinions and interests in the forest. For example, issues discussed might include the pros and cons of clearcutting, the use of chemicals in forest management and climate change issues related to forest management. Material is 
Table 1. Course descriptions for the two undergraduate courses (Current Issues in Forest Science, Forest Ecology) offered through the Department of Environmental Biology ${ }^{1}$, Ontario Agricultural College

ENVB*2030 Current Issues in

Forest Science $^{2}$ F(3-0). [0.50]

Basic principles of forestry and forest management with emphasis on Canada's forests. Relationship of important tree species to their preferred environments. Aspects of tree growth, forest ecology and soils and silviculture. Utilization of forests and trees in the global context. Prerequisites: BIOL*1040

ENVB*4780 Forest Ecology F(2-3). [0.50]

Principles of forest ecology with emphasis on the ecological principles needed for sound forest management. Biotic and abiotic components of forest ecosystems will be discussed in the context of energy flow, nutrient cycling, forest succession and appropriate silvicultural systems. Prerequisites: ENVB*2030, 1 of BOT*2050, BIOL*2060, BIOL*3110.

${ }^{1}$ A diploma course, DAGR*3700 (Agroforestry) and a graduate level course, ENVB*6560 (Forest Ecosystem Dynamics), are also offered through the Department. ${ }^{2}$ Former title: Forestry

drawn from many sources, including Theberge (1989), Kimmins (1997a), Armson (2001) and many others. The fourth-year course in forest ecology explores the flow of nutrients and energy in forest ecosystems, and how these and other characteristics of forests (e.g., biotic wealth, resilience, etc.) can be impacted by management interventions. The course attracts students from many disciplines including natural resources management, botany, geography and especially ecology, where the principles build upon a solid understanding of ecological principles garnered from a suite of excellent courses in this discipline offered through the Departments of Zoology and Botany. Students work from a course reader, which has been legally compiled from a variety of sources (e.g., Hunter 1990, Perry 1994, Kimmins 1997b, Barnes et al. 1998, Aber and Melillo 2001, Wagner and Colombo 2001). A lab, popular with the students, is also associated with the course and involves hands-on fieldwork on a variety of topics: standing crop biomass, net primary productivity, litter decomposition, nitrogen mineralization, and insect diversity. Principles developed in the lab interact with those in ancillary ecology courses that utilize the same woodland setting. Throughout the history of both courses, a debate format has been utilized on occasions to explore ecological and/or management issues in forest systems. These have proven to be highly appreciated by the students, although there is some effort required to make them successful. A suggested format can be found in Gordon (1990). The class notes are available on-line for students in both courses and the latest ones may be viewed at: http://www.uoguelph.ca/ agordon/.

Many other undergraduate courses with a tree and/or forest content exist in many programs across campus. For example, "Woody Plants," offered in the Department of Plant Agriculture, is a popular course, often taken by students in Landscape Architecture. Part of the field of study in horticultural science focuses on helping students understand trees in the urban and near urban environment. The theory and practices of plant propagation are essential to perpetuate seed and asexually propagated woody plants using techniques ranging from genetic manipulation to grafting practices developed thousands of years ago. Tree identification is always combined with understanding cultural adaptation and site tolerances, since urban sites present unique challenges to trees. The study of nursery production practices for the thousands of types of woody plants used in urban and rural landscapes encompasses field and closed environment systems to optimize plant growth and minimize inputs. With an understanding of landscape design, trees become an integral part of the functionality and aesthetics of home, work and recreational spaces.
From a socio-economic perspective, economic models, applications and analysis of the use of forested lands have been a substantive part of several resource and environmental economics course offerings. While these courses include two that are core to the undergraduate B.Sc. Environmental Sciences Program, enrolment typically includes a significant proportion of students who are majors in economics, agricultural economics, international development studies, agriculture, business, engineering, and other disciplines. Forest economics has a unique pedagogical role because the area allows students to combine several concepts in economics and policy that are otherwise often treated separately. Economics of conservation and industrial forestry are treated together, illustrating the complex nature of the economy and the ecosystem. We find that most of our students are demanding that economics be taught in a fashion that is connected with the realities of the current problems in the world around them. Forest economics provides students with challenging and topical opportunities to understand and apply important economic concepts such as discounting, opportunity costs, multiple output production systems, valuation of nonmarket amenities, intergenerational equity and sustainability. Case studies dealing with forest economics research are often featured in coursework in the Department of Agricultural Economics and Business. It has been common for guest lectures to feature faculty involved in forest economics from other universities, as well as from the Ontario Ministry of Natural Resources and other agencies.

These courses, amongst others, have been packaged together to form a minor in forest science at the undergraduate level (Table 2). Students select courses from pre-packaged groupings that account for $25 \%$ of the courses in their undergraduate program. Students successfully completing the minor are identified as such on their graduation diploma; many have reported that it has been useful in conjunction with existing majors (e.g., ecology, natural resources management) in securing employment in the forest sector. With or without using the minor, it is possible for students to obtain a B.Sc. in plant sciences with an emphasis on woody perennials and forested systems.

A variety of field-based courses and field camps are also offered across campus in varying venues (Table 2 ). While these courses do not always explicitly investigate the tree component of the forest, the forest is used as the medium in which to engage in the study of other organisms, as in the case of the field course entitled "Field Entomology" (ENVB*4260). Students enrolled in the minor are also required to take "Research Projects in Environmental Biology" (ENVB*4XXX), which often involves a substantial component of field investigation. Occasionally, these students are aided by high school assistants who are enrolled 
Table 2. The minor in forest science, administered by the Department of Environmental Biology, but available to students in many majors across campus. As of April 2002, courses marked XXX were still under revision. A minor in forest science consists of 5.00 credits (25\% of total required in a four-year program) from the identified groups

Required Courses
BOT*2050
ENVB*2030
ENVB*4XXX
ENVB*4780
HORT*3260

Plant Ecology

Current Issues in Forest Science

Research Projects in ENVB

Forest Ecology

Woody Plants
[0.5], F(3-3) ${ }^{1}$

[0.5], F(3-0)

[0.5], F/W $(0-6)^{2}$

[0.5], F(2-3)

[0.5], F(1-3)

Two from the following group

ENVB*3XXX

$\mathrm{ENVB} * 3 \mathrm{XXX}$

Insects of Natural and Agricultural Systems

[0.5], F(3-3)

Agroforestry System

$[0.5], \mathrm{F}(3-0)$

Ecological Modeling

Biotic and Natural Resources

[0.5], F(1-3)

Nursery Production

Soil Plant Relationships

Environmental Pollution Stresses on Plants

[0.5], W(2-2)

[0.5], W(2-3)

[0.5], W(3-0)

[0.5], W(3-0)

Two from the following group

AGEC*2700

ENVB*3000

GEOG*3210

HORT*3340

SOIL $* 3100$

$\mathrm{ZOO} * 4050$

Survey of Natural Resource Economics

[0.5], W(3-1)

Nature Interpretation

[0.5], F(2-3)

Mgmt. of the Biophysical Environment

[0.5], F(3-0)

Culture of Plants

[0.5], W(3-2)

Resource Planning Techniques

Natural Resources Policy

[0.5], W(2-2)

[0.5], W(3-0)

One from the following group

BIOL*3010

BIOL*4110

SOIL $* 4110$

ZOO*4410

Laboratory and Field Work in Ecology

[0.5], $\mathrm{F}(0-6)$

Ecological Methods

Natural Resources Mgmt. Field Camp

[0.5], F(3-3)

[0.5], F(0-6)

Field Ecology

${ }^{1}$ [credit weight], semester, (lecture hours - lab hours (per week)).

${ }^{2}$ Senior Thesis Topic to be arranged with Departmental Advisor.

in an active high school Co-op program with the University. This program allows high school students to participate in field and laboratory studies and over the years, many have been engaged in forest research activities.

All undergraduate courses are required to address, to the best of their ability, a university-wide set of learning objectives. These are a set of objectives describing the desired characteristics of educated graduates, and are used in part to guide educators in the development of courses and programs. They can be listed as follows: literacy, numeracy, sense of historical development, global understanding, moral maturity, aesthetic maturity, understanding of forms of inquiry, depth and breadth of understanding, independence of thought and love of learning.

\section{Current Status of Forest Education - Graduate}

At the graduate level, as alluded to above, there are numerous courses that involve studying aspects of forests and forest ecosystems. For example, a graduate course entitled "Economics of Renewable Natural Resources" requires students to work on group research projects provided by natural resource management agencies. In the past several years, these class projects have resulted in numerous student papers presented at a variety of conferences. One of the most challenging tasks for the graduate economics students has been learning how to communicate economic ideas and principals in conversations with forest science professionals. Many students report that the problems posed by cross-disciplinary communication was one of the more important lessons they learned from the exercise. Industry and government contacts have repeatedly emphasized the impor- tance of a steady stream of graduates who can function in the combined area of economics, forest management and forestry.

The bulk of graduate level education, however, occurs through the research venue and the offering of M.Sc. and $\mathrm{Ph} . \mathrm{D}$. degrees, and in fact the University of Guelph has historically always had healthy numbers of graduate students in many departments with an interest in the forest. They are involved in a myriad of research topics which embrace the biological, ecological and socio-economic aspects of forestry. For example, for many years researchers have been investigating the unique old-growth cedar (Thuja occidentalis L.) forests of the Niagara escarpment (Fig. 3), nutrient cycling processes in terrestrialaquatic ecotones in central Ontario and in coniferous boreal plantations, forest mycorrhizal systems, the impact of spraying municipal landfill leachate on forest systems, and the evolution of greenhouse gases from tree canopies, to name just a very few. Research on forest systems pervades many academic programs on campus and further embraces, for example, the relationship of entomological, pathological and "wildlife" vectors to the forest environment, physiological and genetic resources, and socio-economic and policy aspects. Research is both basic and applied and, in many instances, is reinforced in the extension realm through the development of landowner education programs such as the one developed in the Department of Land Resource Science to address the conservation of southern woodlands.

\section{Agroforestry}

One unique area of both research and education is agroforestry, the purposeful integration of trees into farming systems. The 


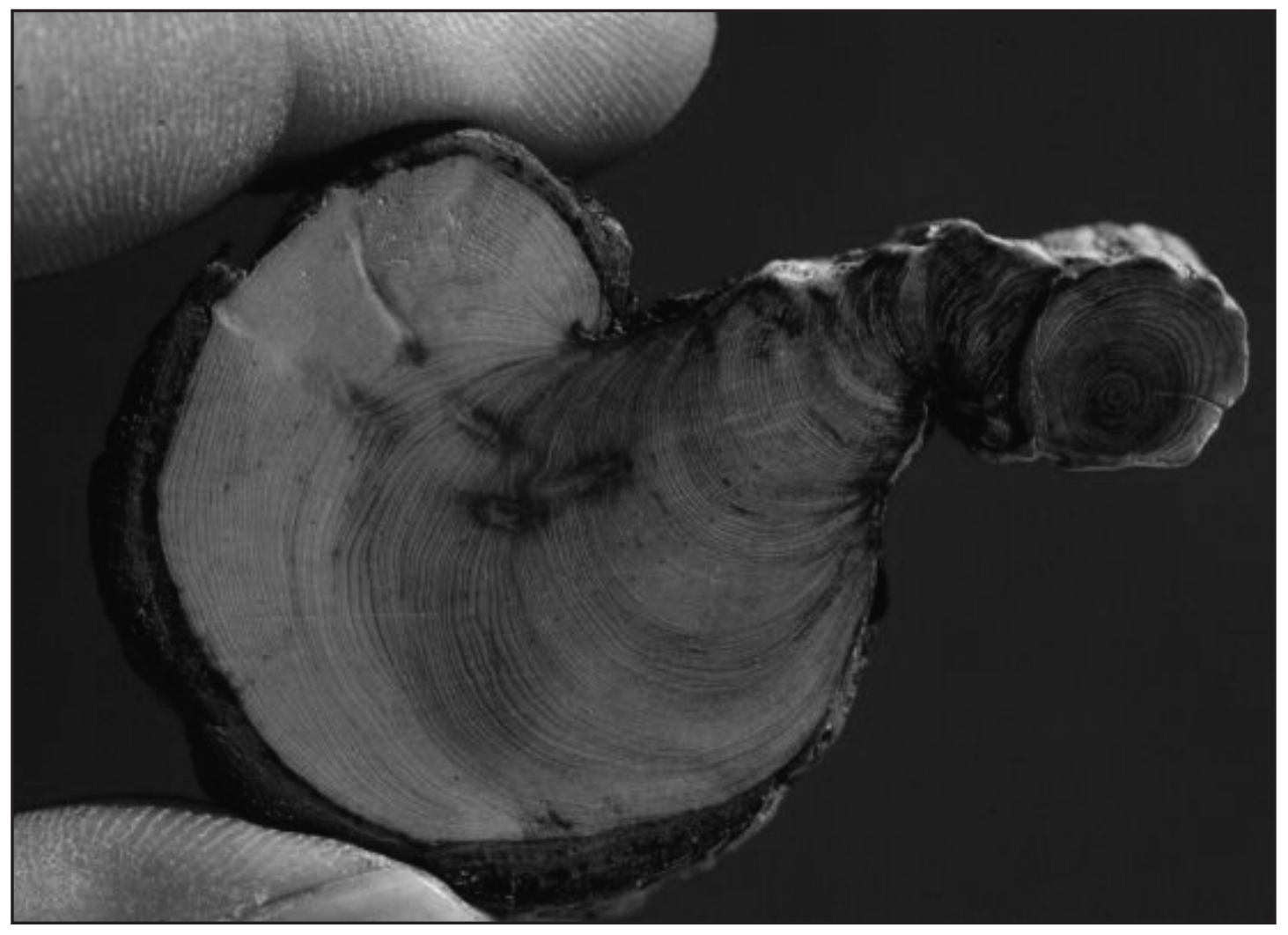

Fig. 3. A cross-sectional disk from an old-growth eastern white cedar growing close to the University of Guelph, on the Niagara escarpment, aged at 322 years (information: http:// www.uoguelph.ca/bot any/ cerg/).

University has gained a worldwide reputation for research in agroforestry and initiated the North American Agroforestry Conference series by hosting the First North American Agroforestry Conference at Guelph in 1989. The University was also a founding member of the Association for Temperate Agroforestry, which has numerous members at many educational institutions across North America.

In addition to an on-going interest in the use and development of tropical agroforestry systems, researchers at the University of Guelph have also investigated the development and role of agroforestry in temperate settings. Early research concentrated on degraded riparian forest environments in southern Ontario but has also addressed windbreak and airflow dynamics, silvopastoral systems and intercropping, the concurrent production of row crops and trees in a profitable and synergistic fashion. The University operates a unique 30-ha intercropping research site (Fig. 4), which is routinely utilized by many undergraduate classes for demonstration and educational purposes. A significant amount of graduate-level research involving numerous domestic and international graduate students is also conducted.

\section{Collaborative Education}

The University has often been in a unique position for collaborative efforts in both education and research programs. In the 1990s, with the University of Toronto and Lakehead University, the University of Guelph participated in the highly successful Ontario Advanced Forestry Program, a continuing education program that embraced autecology, synecology, management, policy and socio-economic aspects of forestry. Graduates of the program praised the learning techniques utilized and many have reported significant positive changes in employment status as a result of participation in the program. The University, again in conjunction with Lakehead University, has also been involved in the development of a distance education Master of Forestry program; two Web-based courses in forest ecology were developed by the University of Guelph (http://www3.open.uoguelph.ca/de/archive/34-698s99/ and http://www3.open.uoguelph.ca/de/archive/34-699s99/), and the first of these won first place at the 1997 North American Web Conference for the Best Educational Web Site, single course category.

\section{Internationalism}

Collaborative educational efforts also extend into the international realm, and indeed internationalism is an integral part of the undergraduate curriculum (Naysmith 2002). With Lakehead University, for example, Guelph has developed agroforestry curricula in association with two CIDA-sponsored projects in Nepal and Ghana, both of which embraced undergraduate and graduate teaching venues in some form. The University also accepts numerous visiting interns in forestry at both the undergraduate and graduate level.

Many researchers at Guelph have international research connections and associated educational opportunities at both the graduate and undergraduate level. As an example, in Honduras, university researchers have found evidence that contradicts the commonly held assumption that tropical forests are being converted to pasture because they are unsuitable for alternative uses (Humphries 1998). Shifting international paradigms uncovered by such research enhances the teaching experience for the undergraduate population and, in addition, often provides overseas educational opportunities for students. 


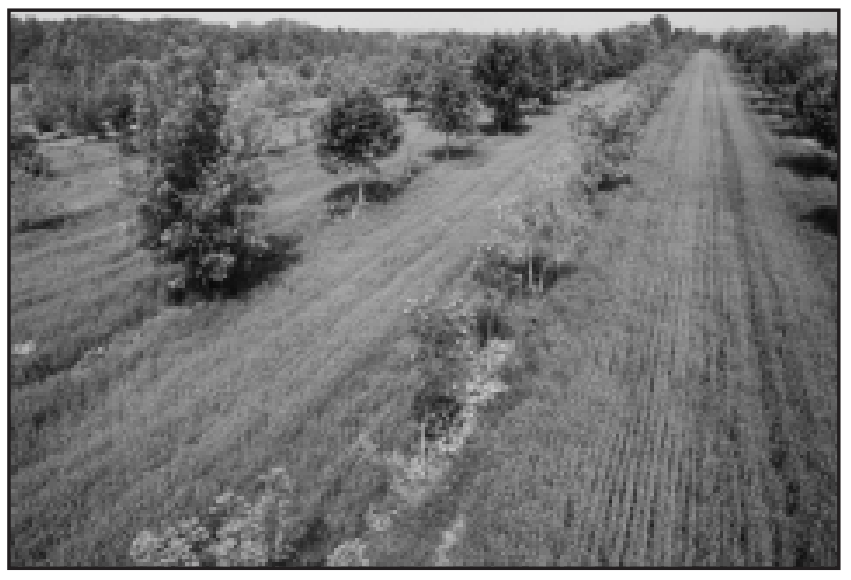

Fig. 4. The University of Guelph Agroforestry Research Station. The inter-cropping experiment encompasses 10 species of trees, 3 crops, 2 alley widths and a variety of soil types. Successful intercropping ventures require the maximization of positive interactions between crops and trees (e.g., litterfall to enhance soil carbon) and the minimization of negative interactions (e.g., shade). This dichotomy allows for development of critical thinking skills, especially at the undergraduate level, where students are asked how to do both at once.

\section{Future Directions and Opportunities}

More than a century has passed since the first forest educational seeds were planted at Guelph, and it seems fitting, in light of the new suite of problems associated with the management of forested lands emerging in the new century, that formalization of education in the forest sciences proceeds at the institution. Coincidentally, the University of Guelph is currently evaluating its options with respect to undergraduate education in the forest sciences. Building on past and present strengths, the University is considering offering a non-accredited B.Sc. program that embraces the science and management of forests and the environmental impact and community benefits associated with interventions in the forest. While this degree will be science-based, opportunities will exist within the curriculum for students to explore the socio-economic aspects of forestry and forested environments. Although the fragmented landscape of southern Ontario and the central hardwood forests immediately to the north are likely to be the geographical region of interest, the current expertise at the University ensures that both a teaching and research presence in the boreal forest will continue. It is the aim of the University to empower graduates of this program, using a learner-centred curriculum, with the system-level biological, ecological and socio-economic knowledge necessary to evaluate ongoing changes in forest policy that may negatively impact on the large array of benefits associated with forested land. The University is currently engaging government and educational partners, other interest groups (e.g., First Nations) and the profession itself, in a dialogue on curriculum development, accreditation and critical direction. Collaborative opportunities will continue to be pursued as appropriate both in the national and international forum and it is the University's intent to build towards the development of an internationally recognized program in the forest environment.

\section{References}

Aber, J.D. and J.M. Melillo. 2001. Terrestrial Ecosystems. Harcourt Academic Press, San Diego, CA. 556 p.

Armson, K.A. 2001. Ontario Forests: a Historical Perspective. Fitzhenry and Whiteside, Markham, ON. 233 p.

Armson, K.A., W.R. Grinnell and F.C. Robinson. 2001. History of reforestation in Ontario. In R.G. Wagner and S.J. Colombo (eds.). Regenerating the Canadian Forest: Principles and Practice for Ontario. pp. 3-22. Fitzhenry and Whiteside, Markham, ON. 650 p. Balch, R.E. 1965. The Ecological Viewpoint. CBC Learning Systems, Toronto, ON. 58 p.

Barnes, B.V., D.R. Zak, S.R. Denton and S.H. Spurr. 1998. Forest Ecology. $4^{\text {th }}$ Ed. John Wiley and Sons, NY. 774 p.

Brassard, G.R. and G. Page. 1994. Measuring the quantity and quality of Canadian forestry research through a survey of publications in Forestry Abstracts, 1978-1992. For. Chron. 70:148-150.

Borczon, E.L. 1982. Evergreen Challenge: The Agreement Forest Story. Ont. Min. Nat. Res., Toronto, ON. 60 p.

Gordon, A.M. 1990. A successful debate format for discussing resource policy issues. J. Agron. Educ. 19: 103-106.

Hills, G.A. 1959. A ready reference to the description of land in Ontario and its productivity. Prelim. Rept., Ont. Dept. Lands and Forests, Toronto, ON. 80 p.

Hills, G.A. and G. Pierpoint. 1960. Forest site evaluation in Ontario. Res. Rept. No. 42, Ont. Dept. Lands and Forests, Toronto, ON. 64 p.

Hunter, M.L. 1990. Wildlife, Forests and Forestry: Principles of Managing Forests for Biological Diversity. Prentice-Hall, NJ. 370 p.

Humphries, S. 1998. Milk cows, migrants and land markets: Unraveling the complexities of forest-to-pasture conversion in Northern Honduras. Econ. Develop. Cult. Change. 47: 95-124.

Kimmins, J.P. 1997a. Balancing Act: Environmental Issues in Forestry. UBC Press, Vancouver, BC. 305 p.

Kimmins, J.P. 1997b. Forest Ecology: A Foundation for Sustainable Management. $2^{\text {nd }}$ Ed. Prentice-Hall, NJ. 596 p.

Lambert, R.S. 1967. Renewing Nature's Wealth: A Centennial History of the Public Management of Lands, Forests and Wildlife in Ontario, 1763-1967. Ont. Dept. Lands and Forests, Toronto, ON. 630 p.

Larson, D.W. 1996. Brown's Woods: An early gravel pit forest restoration project, Ontario, Canada. Restor. Ecol. 4: 11-18.

Naysmith, J.K. 2002. International opportunities for undergraduate forestry students at Canadian universities. For. Chron. 78(2) 231-239. Perry, D.A. 1994. Forest Ecosystems. Johns Hopkins Press, Baltimore. 649 p.

Rimkus, S. and A. Lauzon. 2000. The learning revolution. ACU Bulletin 143: 14-17.

Strategic Planning Commission. 1995. Making Change: a Strategic Plan for the University of Guelph. Final Rept., SPC to the President, University of Guelph, Guelph, ON. 20 p.

Theberge, J.B. (ed.) 1989. Legacy: The Natural History of Ontario. McLelland and Stewart, Toronto, ON. 397 p.

Wagner, R.G. and S.J. Colombo (eds.). 2001. Regenerating the Canadian Forest: Principles and Practice for Ontario. Fitzhenry and Whiteside, Markham, ON. 650 p. 